\title{
PRIMARY AND SECONDARY STRUCTURAL FEATURES IN THE EASTERN PORTION OF THE SOUTH MOUNTAIN BATHOLITH, SOUTHWESTERN NOVA SCOTIA: IMPLICATIONS FOR REGIONAL STRESS ORIENTATIONS DURING INTRUSION
}

\author{
R.J. Horne, M.C. Corey, L.J. Ham and M.A. MacDonald \\ Nova Scotia Department of Mines and Energy \\ P.O. Box 1087, Halifax, Nova Scotia B3J $2 \times 1$ \\ Date Received January 15, 1988 \\ Date Accepted April 27, 1988
}

\begin{abstract}
Primary flow features (schlieren banding, megacryst-xenolith alignment and biotite follation) within the eastern portion of the South Mountain Batholith (SMB) reflect the geometry of intrusions and divides the study area into rwo distinct domains. In the eastern half the primary flow features display roughly concentric to random regional patterns related to differential flowage near contacts. Northeast-trending linear patterns characterize the western half and may in part reflect regional stress.
\end{abstract}

Stereonet evaluation of prominent foints, dykes and veins indigate four primary-regional joint sets (trends), all of which are steeply dipping. The dominant joints, trends $2\left(063^{\circ}\right.$ ) and 4 (145 ) form a roughly orthogonal palr paralle1 and perpendicular, respectively, to the reglonal fold axes. Trends $3\left(130^{\circ}\right)$ and 5 ( $164^{\circ}$ ) form a conjugate set arounc trend 4. Quartz vein orlentations colncide with trend 4 and maxima of dykes correspond to trends 3 , 4 and 5 . Trends 2 to 5 are interpreted as resulting from horizontal compression parallel to trend 4 during a period of uplift. Trend $1\left(042^{\circ}\right)$ is associated w1th a major fault zone wh1ch has locally been superimposed on the pattern of primary-regional joints. Primary-regional joints have to some degree influenced the intrusion of the later phases of the SMB.

Mineralization within the SMB is strongly controlled by the regional fracture patterns. Uranium mineralization generally occurs within altered trend 2 joints whereas polgmetallic vein-greisen mineralization is generally assoclated with trend 4 joints.

\begin{abstract}
Les caractéristiques de flux primaires (rubannement schlieren, alignement des mégacristes et xénolites, foliation de la biot1te) dans la portion orientale du Batholite de South Mountain (BSM) reflétent la géometrie des intrusions et divisent la region etudiee en deux domaines distincts. Dans la demie orlentale les traits de flux primaires se forment en patrons réglonaux, approximativement concentriques à aléatoires, relies au fluage differentiel près des contacts. Des patrons linéares à tendance NE caracterisent la demie occidentale et pourraient représenter, en partie, une contrainte régionale.
\end{abstract}

Une évaluation sur stêrenet des diaclases, dykes et veines évidents révéle quatre familles (tendances) de diaclases primaires régionales agant toutes un pendage élevé. Dominantes, les familles directionnelles de fractures 2 ( $063^{\circ}$ ) et $4\left(145^{\circ}\right)$ forment une paire plus gu moins orthogonale, respectivement parallele et perpendiculaire aux axes de plis réglonaux. Les tendances $3\left(130^{\circ}\right)$ et $5\left(164^{\circ}\right)$ forment une famille conjuguee autour de la tendance 4 . $L$ 'orientation des veines de quartz colncide avec la tendance 4. Le nombre maximum de dykes correspond aux familles directionnelles 3, 4 et 5 . On interprete les tendances 2 a 5 comme résultant d'une compression horizontale parallesle a la famille 4 lors d'une pérlode de surrection. La tendance $1\left(042^{\circ}\right)$ s'associe à une zone de fallle majeure superposée localement au patron des fractures primalres reglonales. Ces derniers ont exerce une certaine influence sur 1 '1ntrusion des phases tardives du BSM.

Les patrons de fractures régionaux ont fortement contrôle la minéralisation à 1'1ntérieur du BSM. La minéralisation en uranium occupe genéralement des famlles directionnelles 2 altérées. Par contre, les minéralisations de type greisen ou filon polymetallique sont generalement associes aux diaclases de tendance 4.

[Tradu1t par le journal]

\section{INTRODUCTION}

Previous studies in the South Mountain Batholith (SMB) have indicated that it is massive, generally lacking significant primary or secondary structure. Limited assessment of primary flow features (McKenzie, 1974; Abbott, in Clarke and Muecke, 1980) and joint and dyke patterns (McKenzle, 1974; Charest, 1979) documented some systematic patterns to these structural elements; however, none of these studies considered these patterns with respect to the geology of the batholith.

Flow features within granitic rocks (schileren banding, megacryst and xenolith alignment, and biotite follation) are generally considered to result from differential flow related to intrusion, developing as planar features (Ba1k, 1937; Martin, 1953; Hutchinson, 1956; Davis, 1963; Allen, 1966; Marre, 1986). Thus, patterns of flow features usually reflect the geometry of the intrusions.
Primary joints within granitic rocks reflect the ambient stress at time of intrusion. The stress can be both local and related to emplacement and cooling of the intrusion and/or regional and related to regional tectonism. Fracture systems related to emplacement and cooling are generally characterized by complex concentric and/or radial patterns (Knapp and Norton, 1981; Koide and Bhattachar $j 1,1975)$ and are suggested to be geometrically related to primary flow features (Ba1k, 1937; Martin, 1953; Hutchinson, 1956; Davis, 1963; Allen, 1966; Marre, 1986). In contrast fractures related to regional stress generally exhibit regionally consistent linear trends and display a uniform relationship to regional tectonic trends (e.g.. those associated with Laramide intrusions in Arizona: Heidrick and Titley, 1982; Rehrig and Heidrick, 1972).

The present study results from recent $1: 50,000$ scale geological mapping of the eastern portion of MARITIME SEDIMENTS AND ATLANTIC GEOLOGY 
the SMB (MacDonald et al., 1987), during which attitudes of structural elements (flow features, joints, dykes, veins) were collected. This paper addresses the patterns reflected by flow features and fractures in the eastern portion of the SMB. The joint patterns presented here are, for the most part, represented by trends defined by maxima on stereonet plots.

\section{REGIONAL SETTING}

The SMB is a large (approximately $10,000 \mathrm{~km}^{2}$ ) peraluminous, arcuate-shaped, composite batholith which underlies much of southwestern Nova Scotia (Fig. 1). The depth of intrusion has been estimated at between 4-10 km (1.e., eplzonal; McKenzie and Clarke, 1975). The SMB intruded CambroOrdovician metasedimentary rocks of the Meguma Group which consist of metawackes of the lower Goldenville Formation and slates and siltstones of the overlying Halifax Formation. Along its northern margin, the SMB also intruded Ordovician to Lower Devonian metasedimentary and metavolcanic rocks of the White Rock, Kentville, New Canaan and Torbrook Formations, which conformably overlie the Meguma Group. Th1s sequence was folded into northeast-trending (in the study area), upright, doublyplunging folds during the mid-Devonian Acadian Orogeny. The axes of these folds define the dominant structural fabric in the Meguma Terrane (Fig. 1). Regional metamorphism grades within the Meguma Group ranges from lower greenschist to lower amphibolite facies and is locally overprinted by low pressure contact metamorphism related to granite intrusion, manifested in the development of a hornblende-hornfels facies aureole (Taylor and Schiller, 1966). The SMB truncates the regional fold trends, is generally unfollated and hence post-dates the major deformational events of the Acadian Orogeny (Wright, 1931; McKenzie and Clarke,
1975). A weak follation of cordierite in the contact aureole (Hanmer in; Clarke and Halliday, 1980) suggests a late, syn-to post-tectonic emplacement.

Paleontological evidence from the Torbrook Formation and Lower Carboniferous strata, which are, respectively, intruded by and unconformably overly the SMB, bracket the intrusion, uplift and erosion of the SMB to the interval between Emsian and Tournaisian time. Uplift must, therefore, have been relatively rapid. Isotopic dating (Clarke and Halliday, 1980; Reynolds et al., 1981) concurs with this evidence and indicates a range from $372 \mathrm{Ma}$ to $361 \mathrm{Ma}$ for the intrusion of the batholith.

\section{GEOLOGY OF THE SMB}

The geology of the eastern portion of the SMB has recently been described by MacDonald et al. (1987) and a summary of this work is presented here (Fig. 2). Granitold rocks exposed in the study area have been divided into eight 11thologic groups: (percentage of total exposed granite in brackets) (1) mafic porphyry $(<1 \%)$, (2) granodiorite (16\%), (3) biotite monzogranite $(34 \%)$, (4) muscovitebiotite monzogranite (13\%), (5) medium- to coarsegrained, megacryst1c leucomonzogranite (25\%), (6) equigranular to porphyritic leucomonzogranite $(10 \%)$, (7) intrusive suites $(1 \%)$, and (8) leucogranite and leucogranite suites (1\%). Each of these groups is represented by several discrete mappable units exhibiting both sharp and gradational contacts, suggesting a complex intrusive history. For complete unit descriptions see MacDonald et al. (1987).

Within the map area the SMB includes three composite plutons. These consist predominantiy of leucomonzogranite with lesser amounts of muscovitebiotite monzogranite and leucogranite and have intruded an envelope of biotite monzogranite and

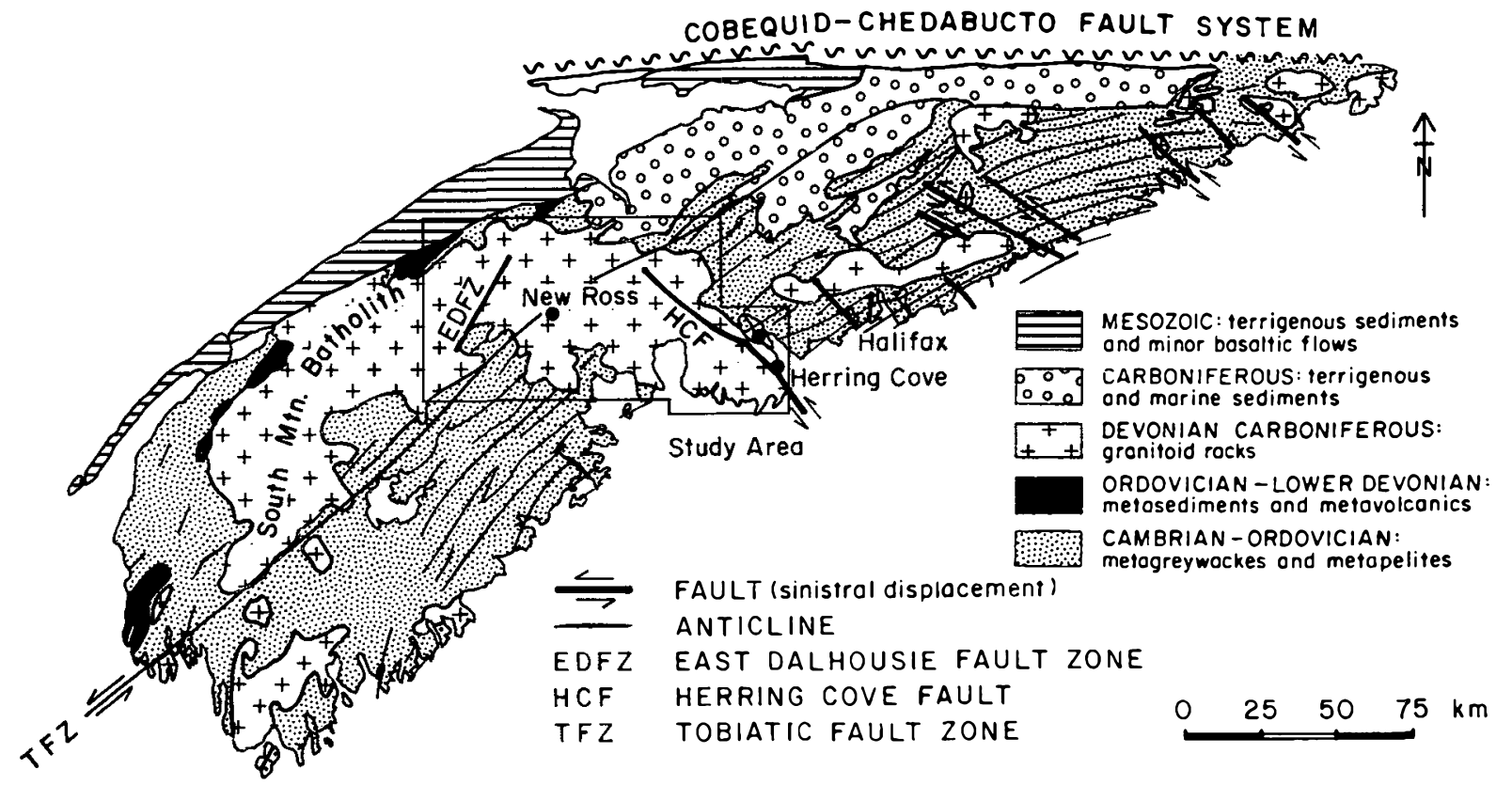

F1g. 1. Generalized geological map of southwestern Nova Scotia south of the Cobequid-Chedabucto Fault System (Meguma Zone). showing location of study area in the eastern part of the South Mountain Batholith. Major faults shown are as follows: EDFZ - East Dalhousie Fault Zone; TFZ - Toblat1c Fault Zone; HCP - Herring Cove Fault. 


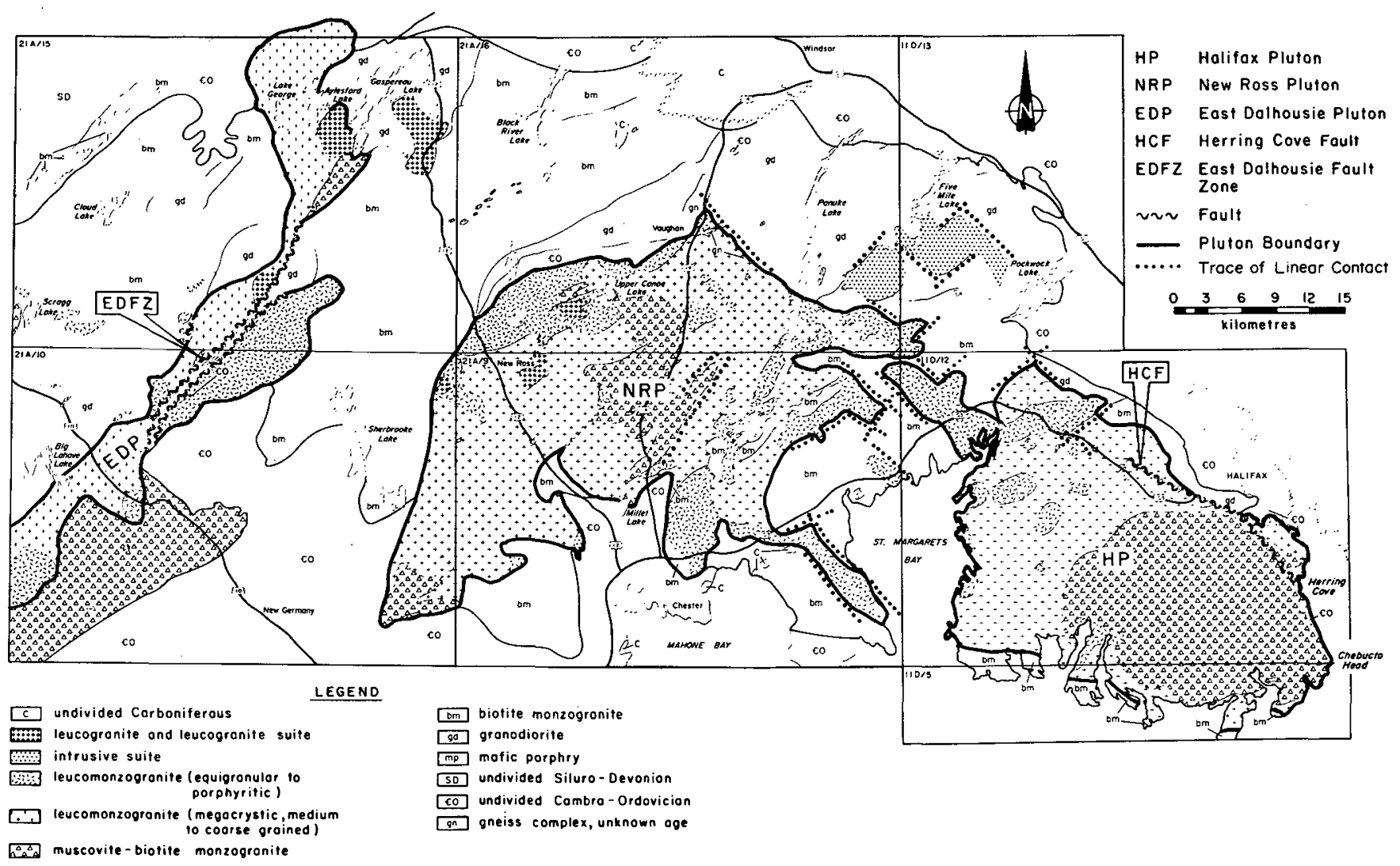

F1g. 2. Geological map of the eastern portion of the South Mountain Batholith (after MacDonald et al.. 1987) out1ining the three major plutons: HP - Halifax Pluton; NRP - New Ross Pluton; EDP - East Dalhousie P1uton.

granodiorite. The plutons are referred to as the Hallfax Pluton (HP), the New Ross Pluton (NRP) and the East Dalhousie Pluton (EDP) (F1g. 2). The HP and NRP are rough1y circular in out1ine whereas the EDP is linear in shape. Field relationships between the NRP and EDP and the envelope of biotite monzogranite and granodiorite are everywhere sharp. However, both sharp and gradational contacts are evident between rocks of the HP and its mafic envelope.

\section{EMPLACEMENT OF THE SMB}

Contacts with the country rock are sharp and discordant and there is generally no appreciable emplacement-related follation in either the granitic or country rocks. Minor exceptions are found in the local parallelism of megacrysts to contacts and minor deformation of the Meguma Group in the Chester Basin area (McKenzie, 1974; 0'Brien, 1986).

Reglonal stratigraphy and structural elements within the Meguma Group generally show minimal deflection or distortion due to the presence of the SMB and can be traced across embayments of granitic rock. Large inllers of Meguma Group rocks (roof pendants?), such as the one along the northwestern edge of the NRP (Fig. 2), display structural conformity with regional trends. A single exception is found in a "transverse anticline" and "transverse syncline" mapped by Fartbault (1908) at the eastern end of the SMB, near Hallfax. These structures are oriented perpendicular to the regional trend, suggesting possible lateral thrusting due to granite intrusion (Wright, 1931). The above features, coupled with an abundance of xenoliths (country rock?) which show no obvious spatial relation to country rock contacts, have been interpreted to indicate that magmatic stoping was the dominant mechanism of intrusion for the SMB (Wright, 1931; McKenzie 1974).

\section{PRIMARY FLOW STRUCTURES WITHIN THE SOUTH MOUNTAIN BATHOLITH}

Primary flow features are generally not abundant within the SMB, probably reflecting the passive style of its emplacement. However, some of the features and the patterns they define are discussed below.

\section{Sch1leren Banding}

Schlieren banding, generally consisting of biotite-rich layers and less common banding of leucocratic phases, occurs sporadically throughout the batholith. It is most common in biotite monzogranite and granodiorite. Schlieren bands range from less than a metre to several metres and, occasionally, several tens of metres, in length. They are most abundant close to intrusive contacts which they commonly paralle1, and are considered to have developed in the plane of flow. As most schlieren is observed only on horizontal outcrop surfaces, its three-dimensional configuration is rarely known. 
F1ow Concentrations of Megacrysts and/or Xenoliths

Small discrete areas (approximate1y 1-10 $\mathrm{m}^{2}$ ) consisting of concentrations of megacrysts and/or xenoliths are common in some units throughout the SMB. They are thought to represent physical separation and concentration of larger elements within the magma. These features are not planar and no apparent cause for their localization has been determined.

\section{Megacryst-Xenolith Alignment}

Megacrystic units 1ocally exhibit a weak to moderate alignment of megacrysts which is considered to have resulted from parallel alignment of the larger crystal faces with the flow plane of the magma. If so, these features represent flow follations. Because of the difficulty in determining the crystallographic axes of megacrysts on flat outcrops, the linear component of this follation, if present, remains unknown. The development of megacryst alignment is not uniform on either outcrop or regional scale. Locally elongate (tabular?) xenoliths are orlented paralle1 to the megacryst alignment.

Megacrysts locally allgn parallel to contacts; however, this is not a common feature and no evidence of flow follation. Is generally present at contacts. In other areas, megacryst alignment defines 'swirl' patterns on an outcrop scale. These have been interpreted to represent "convective motion" (McKenzie, 1974). Abbott (in Clarke and Muecke, 1980 , p. 30) mapped large scale (hundreds of metres) concentric patterns in the muscovite-biotite monzogranite around Chebucto Head which he attributed to convective processes.

\section{Regional F1ow Patterns}

Regional patterns defined by megacryst alignment and schlieren banding can be identified in three areas; measurements of megacryst alignments used to define regional patterns are limited to those which are consistent in orientation on the outcrop scale:

1) Within the rocks of the HP, preferred orlentations of megacrysts trend parallel to the contacts of the pluton, and thus define a crudely concentric pattern (Fig. 3). Schlieren banding typically complements megacryst alignment, both in distribution and orientation. Although only poorly and locally developed, the pattern suggests differential flow past the wall rocks during emplacement.

11) The preferred alignment of megacrysts within the leucomonzogranite of the NRP also defines a concentric pattern parallel to the contacts of the pluton (Fig. 3) and is similarly attributed to differential flow during emplacement.

111) A preferred northeast-trending alignment of megacrysts is common in the northwestern part of the study area, particularly in the biotite monzogranite and granodiorite west of the EDP. As evident in Figure 3, the occurrence of flow features is much denser here than elsewhere in the SMB. The northeasterly trend roughly parallels country rock-granite contacts, granite-granite contacts and fold axes within the country rocks. Elongate xenoliths and a local, well defined, vertical biotite follation (Smitheringale, 1973) parallels and enhances this flow pattern.

The linear pattern of flow features in this area contrasts sharply with the circular patterns assoclated with the NRP and HP. Regardless of the interpretation of the development of megacrystxenolith alignment and schileren banding, this contrast clearly separates the area into two distinct domains (east and west). The separation of these 'domains' is consistent with the general geometric style of intrusions in the study area, concentric in the east and northeast-1inear in the west (F1g. 2), and thus can be approximated by a line along the northwestern side of the NRP and the contact between the granodiorite and biotite monzogranite units north of the NRP (Figs. 2, 3). The separation of these domains is broadiy consistent with, and may reflect, the Tobiatic Fault Zone (F1g. 1; Giles, 1986).

\section{FAULTS}

\section{Herring Cove Fault}

The Herring Cove fault (HCF) (MacDonald and Horne, 1987) is a major northwest-trending structure extending along the northeastern boundary of the HP (Fig. 2). Deformation is characterized by brittle features involving significant grain size reduction and accompanied pervasive chloritization and lesser hematitization within the fault zone. Sinistral displacement of at least one kilometre 1s suggested by the offset of contacts between megacrystic leucomonzogranite and muscovite-biotite monzogranite in the area of Herring Cove (Fig. 2).

The HCF parallels and may be genetically linked to several sinistral transverse faults which offset folds within the Meguma Group. These are particularly common east of the SMB (Cameron, 1956; Fyson, 1966; Kepple, 1979) and have been suggested to record early Mesozolc deformation within the Meguma Terrane (Keppie, 1987).

\section{East Dalhousie Fault Zone}

The East Dalhousie Fault Zone (EDFZ) (MacDonald et al., 1987) is a northeast-trending brittle structure located within the EDP. Deformation resembles that within the $\mathrm{HCF}$. Faulting is manifest largely within a wedge of biotite monzogranite(?) which bisects and rough1y parallels the EDP over a distance of approximately $17 \mathrm{~km}$. This wedge is locally in faulted contact with rocks of the EDP, indicating therefore that faulting post-dated intrusion of the EDP. The elongate outcrop expression of the EDP suggests it was intruded along a linear feature and the coincidence of this linear feature with the EDFZ suggests a link between the two. However, there are insufficient data to speculate on the relative ages of intrusion of the EDP and the EDFZ.

The small linear leucomonzogranite bodies northwest of the NRP also trend northeast and evidence of faulting within them has been documented by 0'Reiliy (1987). O'Reilly (1987) suggested that these bodies intruded a northeasttrending fracture system and that post-emplacement shearing occurred along this fracture system. 


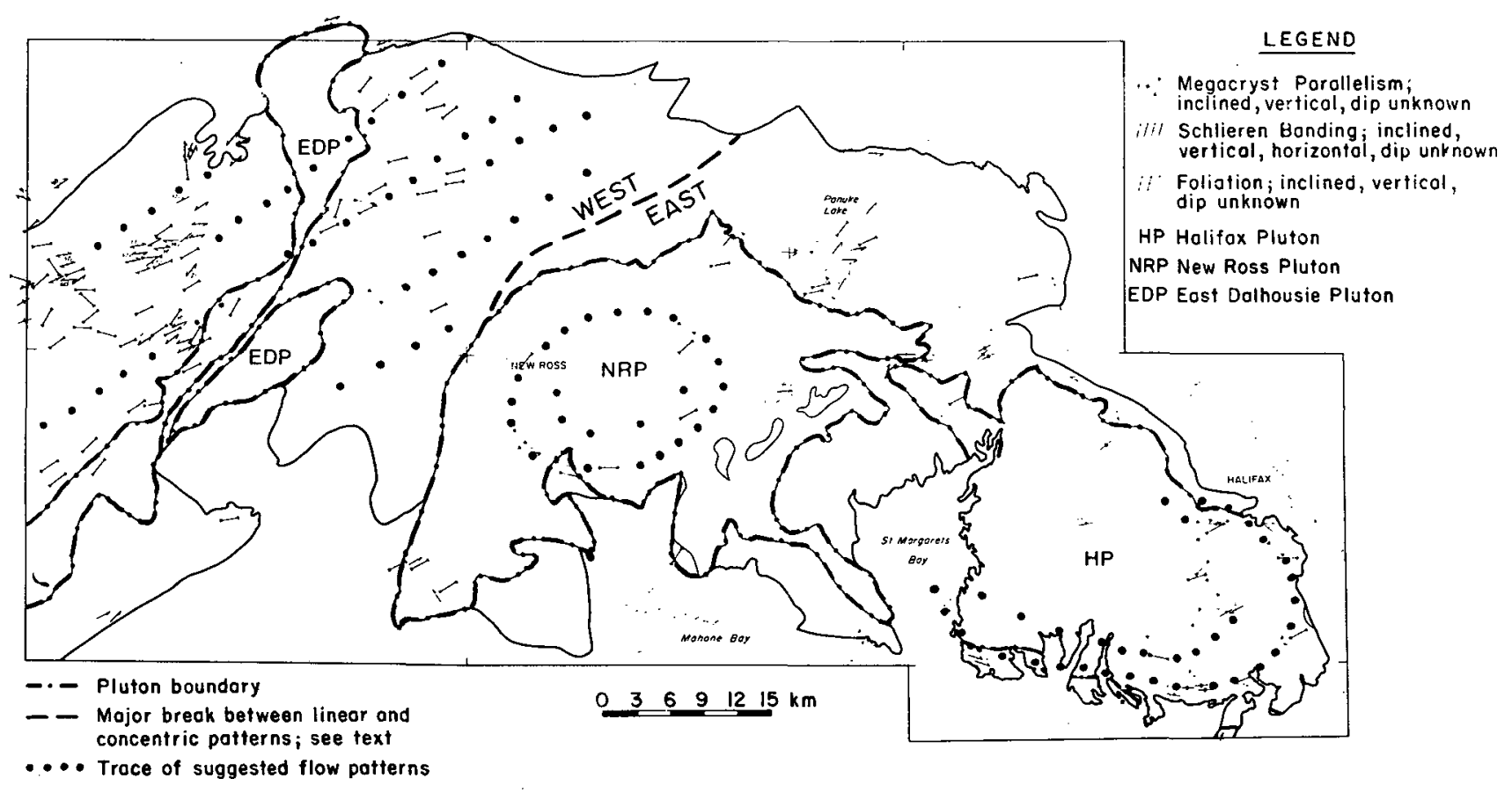

F18. 3. Distribution and orlentation of flow features (aligned megacrysts, schlieren banding and biotite foliation) in the eastern portion of the South Mountain Batholith.

\section{JOINTS, DYKES AND VEINS}

The attitudes of foints, dykes and veins were routinely recorded as part of $1: 50,000$ scale mapping of the eastern portion of the SMB. Generally 1-3 joint measurements were recorded at each outcrop and the attitudes of most dykes and velns were also measured. There was no predesigned procedure for joint selection and, although only a limited number of foints were measured at any one outcrop, the number of outcrops examined was large $(>1000)$ and thus the data set is considered to be representative of the dominant joint trends.

The distribution of data is not uniform due to variation in the number of measurements and the relative density of outcrop. However, the variation is not more than $2: 1$ and does not appear to affect the resultant patterns.

The relative age and geometric relations between the varlous structural elements were rarely recorded so 1ittle quantitative information is known concerning the relationships between them. There was also no systematic attempt to classify Joint type and thus the resulting data set is a composite of fracture types. Fracture patterns, therefore, may reflect the combined influence of primary and secondary fractures resulting from both local and regional stress systems.

Joint, dyke, and vein data sets were created for each of the map units (Fig. 2) and subsequently compiled into larger sets, the selection of which is detalled below. Computer generated Schmidt stereonets (H.A.K. Charlesworth, unpublished computer program for stereonet) of density contoured poles to planes were used to assess the joint, dyke, and vein orlentations.

\section{Joints}

The term joint refers to planar fractures along which little or no displacement has occurred. However, for the purpose of this paper, joint sets are a composite of fractures, dykes, and veins. Joints are best observed in vertical sections such as those exposed along major highways. Most exposure in the SMB, however, is relatively flat and does not present jointing well. Flat-1ying joints in particular have probably been largely overlooked due to unfavorable exposure; in many vertical exposures a ve11-developed subhorizontal joint set is present. In general, the character of the foints is 11thology controlled, with the best developed joints occurring within fine- to mediumgrained equigranular units where a blocky joint pattern is common. Jolnting within the coarser grained units is usually less apparent although vertical sections in such rocks commonly reveal we11 developed foints. Lithologic control of joint development in granttes has also been documented by Fireman (1960) and Suryanarayana (1978).

Joints have been complled into a number of subsets representing certain intrusive features within the study area, in order to assess the possible influence of emplacement related stresses on foint formation (Knapp and Norton, 1981; Koide and Bhattacharf1, 1975; Balk, 1937; Mart1n, 1953; Hutchinson, 1956; Dav1s, 1963; Allen, 1966; Marre, 1986). The most obvious are the three major composite plutons (HP, NRP and EDP), which are considered to represent distinct intrusive events. each having a separate history of emplacement and cooling. Additionally, data subsets were also created for the east and west half of the study area, according to the division based on intrusion 
geometry and flow patterns discussed above, and for the entire area.

Stereonets of the above data sets (Figs. 4a-f) indicate that steeply dipping, roughly orthogonal trends (northeast and northwest) are the dominant joints in all data sets. These trends are represented by well developed maximas or submaximas of a paired maximum. A synoptic plot from each of the $1: 50,000$ scale map sheets, as we11 as plots for selected 1ndividual map units (Horne, 1987; Horne, unpublished data), are also dominated by the same trends. Published joint analyses for the central portion of the SMB (McKenzle, 1974; F1g. 5a), the northwestern portion of the study area (Smitheringale, 1973; Table 1), and the area around New Ross (Charest, 1979;. Fig. 5c) also Indicate trends consistent with those of this study. Thus, regardless of scale or geology, similar joint trends exist throughout the study area.

Table 1 summarises foint trends by 11sting the orientations of joint maxima and submaxima for each of the above data sets. Five separate joint trends have been 1dentifled, all of which are steeply dipping and will be referred to only by strike orientation.

The most persistent fracture trends occurring in a11 data sets are trends $2\left(063^{\circ}-065^{\circ}\right)$ and $4\left(144^{\circ}\right.$ $146^{\circ}$ ), forming a nearly orthogonal pair of joint sets parallel and perpendicular to the regional fold trends, respective1y. These foint trends represent consplcuous features in many outcrops and a qualitative description based on observations from selected locations is given below.

\section{Trend 2 Joints}

Trend 2 joints are generally poorly developed, have irregular, curviplanar surfaces and are irregularly spaced. They are locally tightly spaced $(0.1-1 \mathrm{~cm})$ and can develop spaced fracture cleavage. Where this occurs the rock appears sheared, although xenoliths and megacrysts within zones of fracture cleavage are not displaced. Fracture cleavage is most commonly observed within leucomonzogranite units and is usually accompanied by intense alteration (hematitization). Many of these NE-SW trending altered fracture zones host significant uranium mineralization (e.g., Millet Brook uranium deposit).

\section{Trend 4 Joints}

Trend 4 joints form the dominant set in many areas. They are generally well developed and regularly spaced (1-2 $\mathrm{m})$ with straight continuous joint planes. Individual foints have been observed to extend for hundreds of metres and in many areas a ridge and swale topography is controlled by these joints. Joint surfaces are commonly encrusted with sericite \pm chlorite \pm fluorite \pm pyrite, and foints of this set are the dominant hosts of quartz veins, grelsens, and dykes (Table 1).

The relationship between foint sets 2 and 4 is locally well exposed. On Whale Lake, at the southwestern corner of the NRP, a well developed northwest-trending joint set (trend 4) forms the dominant structure. These foints are locally filled with aplite dykes, quartz veins (some of which are mineralized) or crusts of sericite. Veins within trend 4 joints cross-cut (post-date) a
Fig. 4. Contoured density plots of poles to: (a) all joints $(n-3600)$ in the eastern portion of the SMB; (b) all foints in the eastern portion of the study area $(n-1300)$; (c) all jolnts in the western portion of the study area (n-2300); (d) all foints in the Hallfax Pluton (n-317); (e) all joints in the New Ross Pluton (n-700); (f) all joints in the East Dalhousle Pluton (n-183); (g) all veins in the study area $(n-381)$; and $(h)$ all dykes in the study area $(n-640)$. Numbers refer to trends as discussed in text.
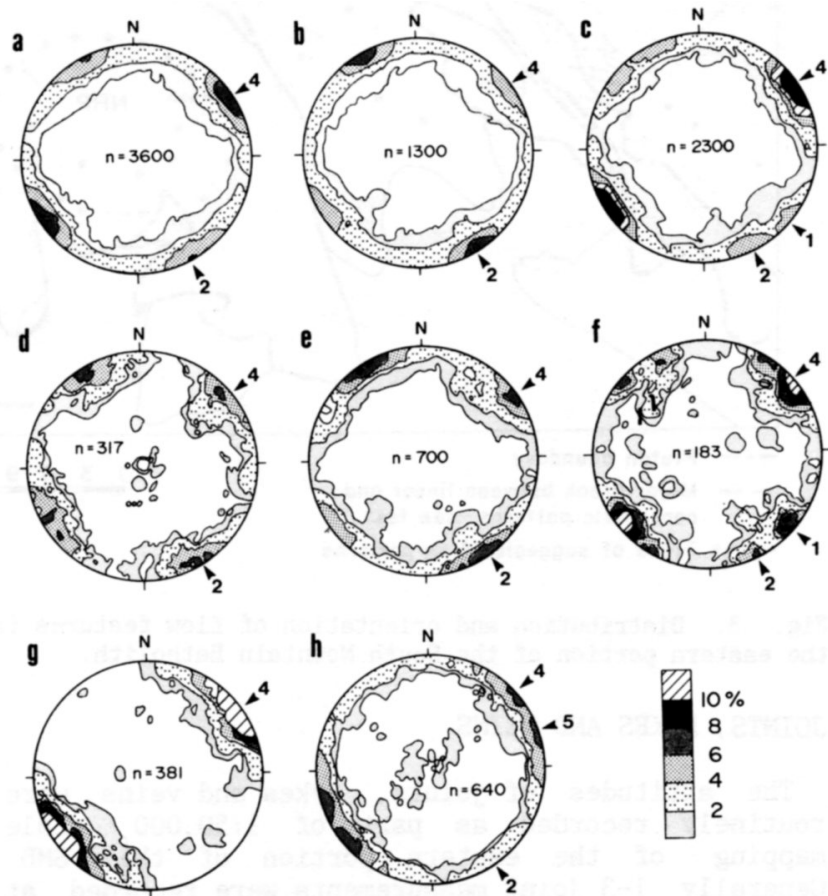

F1g. 5. Published data of contoured density plots of poles to: (a) joints in the central portion of the South Mounta1n Batholith (n-566); (b) dykes + veins in the central portion of the South Mountain Batholith (n-134); and rose diagrams of: (c) joints in the New Ross area $(n-101)$ (d) dykes + veins in the New Ross area (n-64); [a and b from McKenzie, 1974; $c$ and $d$ from Charest, 1979]. Numbers refer to trends as discussed in text.
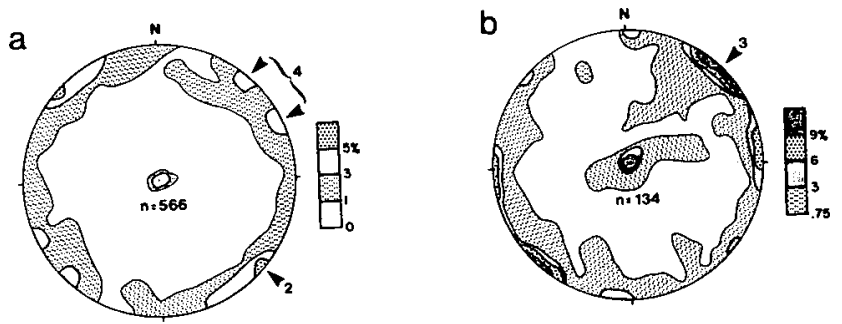

C

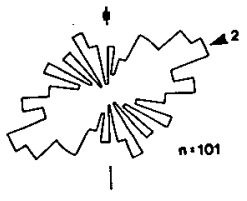

d

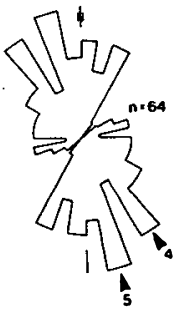


Table 1. Summary of joint, dyke and vein trends in the eastern part of the South Mountain Batholith (SMB). SMB - entire study area; East and West the eastern and western halfs of the study area as discussed in test; HP = Halifax Pluton; NRP $=$ New Ross Pluton; EDP - East Dalhousle Pluton.

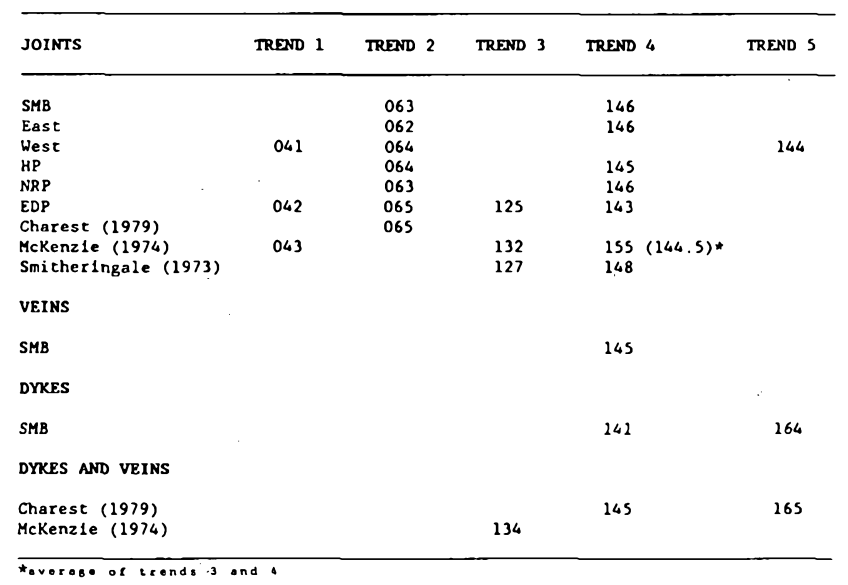

subordinate set of mutually perpendicular (trend 2) joints which are poorly developed and irregular. Similar relationships have been noted elsewhere, with veins and planar joint surfaces of trend 4 joints cross-cutting trend 2 fracture cleavage. However, trend 4 dykes are also locally cut by trend 2 joints, suggesting both joint sets developed closely in time.

\section{other Joint sets}

Trend $1\left(041^{\circ}\right)$ is a well pronounced submaxima of a paired maximum and is restricted to data sets of the EDP and western portion of the study area (Table 1). This joint trend is roughly parallel to the EDFZ.
Trend $3\left(130^{\circ}\right)$ is represented by a submaxima in data sets of fractures in the EDP (McKenzie, 1974; Smitheringale, 1973). In the case of McKenzie's data, however, the average of this trend and another submaxima is equal to trend 4. Trend three is also represented by dykes (Fig. 5b).

Trend $5\left(164^{\circ}\right)$ is represented solely by dykes (Table 1) in data sets of this survey and McKenzie (1974). Neither trend 3 or 5 are recognized in the field and their poor representation is probably reflecting the fact that generally only the dominant joints were recorded. The distinct representation by dykes and/or veins, however, is convincing evidence that these trends are significant.

Lineaments defined from air photo interpretation (Fig. 6) are coincident with northeastly and northwestly joint trends. The only area showing any major departure from this pattern is located in the north-central portion of the study area where a pronounced north-south trend is present.

Quartz Veins

Both mineralized and barren quartz veins are predominantly developed in dilatant joints, although some represent replacement features. Greisen selvages are commonly associated with veining. Quartz veins in the study area are restricted to trend 4 joints (Fig. $4 \mathrm{~g}$, Table 1 ), as is readily apparent when veins are plotted on a map (Fig. 7a). This northwestly trend of quartz veins was noted by MacDonald and Horne (1987) in the Tantalion area (northwestern portion of the HP) where numerous veins are present. Within the study area, quartz veins are approximately uniform in distribution (Fig. 7a) with areas of low vein densities generally corresponding to areas of poor outcrop. However, many of the veins associated with the leucomonzogranitic units are characterized by greisen borders and $\mathrm{S} n \pm W \pm \mathrm{Cu} \pm \mathrm{Mo} \pm \mathrm{As}$ mineraliza-

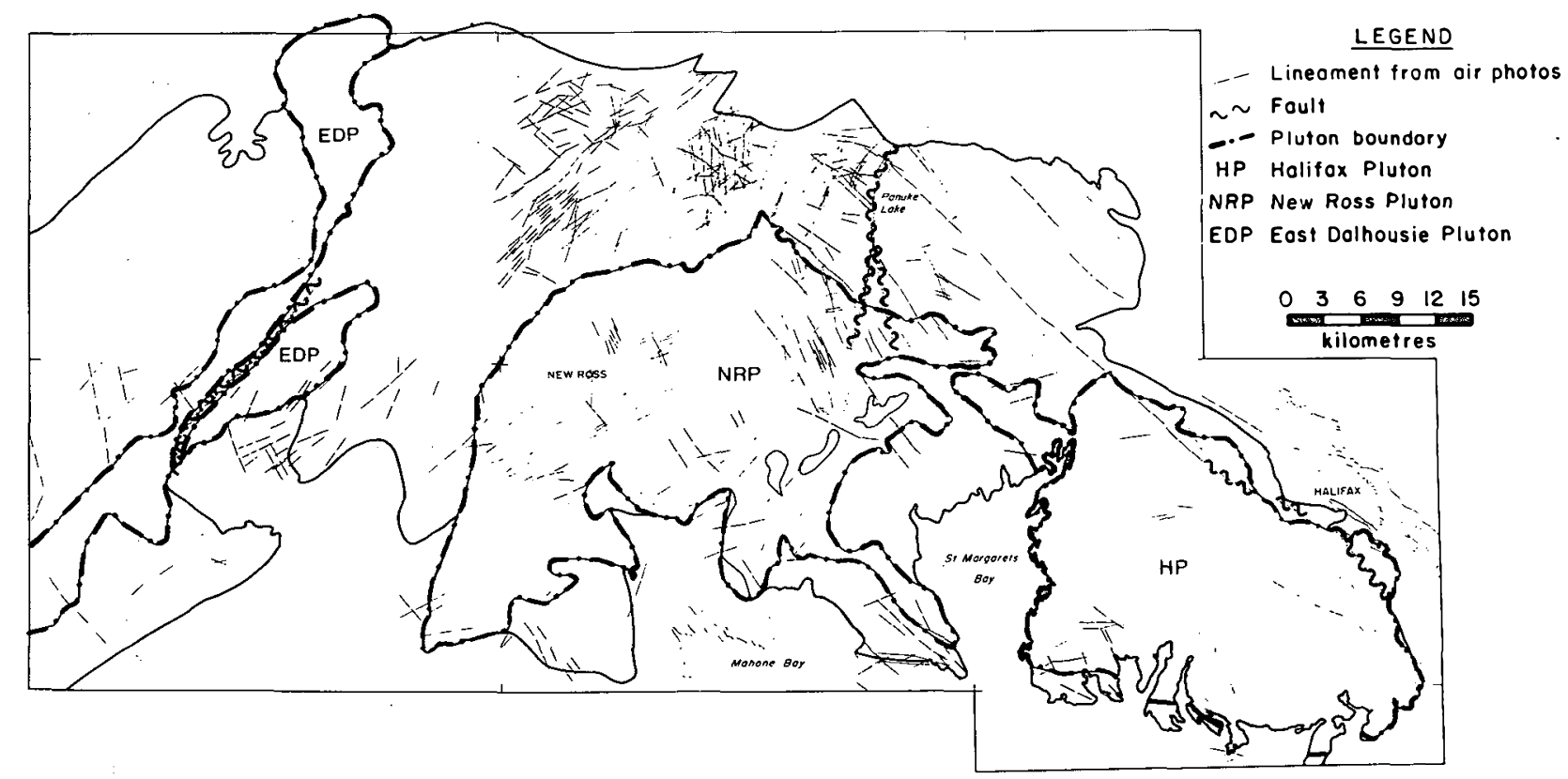

F1g. 6. A1r photo interpretation of 11neaments in the eastern portion of the South Mountain Batholith. Information complled from P. Finck and M. Graves, unpublished data. 
tion, whereas most veins within biotite monzogranite and granodiorite are barren or contain only pyrite and/or arsenopyrite.

Dykes

Dyke 1ithologies include, in order of decreasing abundance, aplite, pegmatite, composite aplitepegmatite and minor amounts of granitoid units. Dyke orientations are not as clustered as those of the quartz veins and dip steeply in a11 orientations (Fig. 4h). However, there is a maxima corresponding to that of quartz veins (Fig. 4h). A similar situation was found by Rehrig and Heidrick (1972) for dykes and veins in Laramide plutons in Arizona. It may reflect the timing of their emplacement. Hence, co-magmatic dykes were intruded during the early stages of crystallization and hydrothermal quartz veins represent latemagmatic to early post-magmatic features. Joint patterns would presumably be more extensive at the time of vein formation. This sequence of dyke and vein formation has been well documented elsewhere (Allen, 1966; Parslow, 1968). Other submaxima of dykes correspond to trends 3 and 5 (Table 1). A set of subhorizontal dykes (Figs. 4h, 5b) confirms the presence of subhorizontal joints.

The distribution of dykes is roughly uniform throughout the map area, although their orientation shows considerable variation (Fig. $7 b$ ). In some areas dyke trends parallel veins whereas in others they are apparently random. A systematic relation-
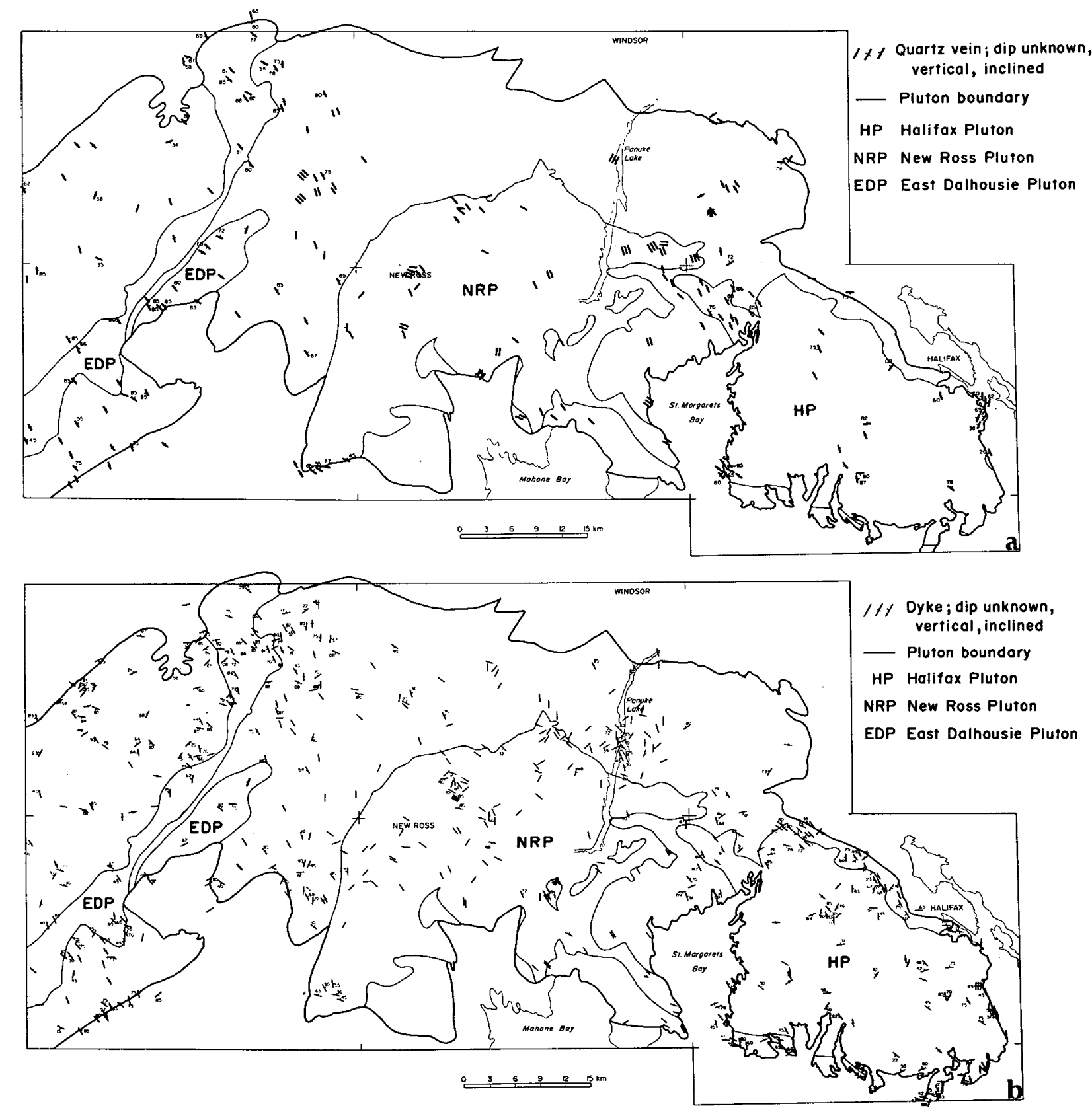

F1g. 7. Distribution and orientation of (a) dykes and (b) veins in the eastern portion of the South Mountain Batholith. 
ship 1ocally exists between dyke orlentation and the geometry of units (e.g., where dykes paralle1 the granite-metasedimentary rock contact).

\section{Joint Contro1 on Granite Emplacement}

Linear contacts between and within the NRP, HP, the intrusive suite body in the northeastern corner of the study area and the envelope rocks, display orientations roughly coincident with the major joint trends ( 2 and 4 ). These contacts have been highlighted in Figure 2. In some areas, such as the intrusive suite referred to above and the contacts of the HP and NRP with the envelope north of St. Margarets Bay, a box-11ke geometry is apparent. This strongly suggests that at least locally joint development influenced the emplacement of the later units of the SMB. Control on granite emplacement by regional joint systems has been we11 documented within the Coastal Batholith of Peru (Knox, 1974; Busse11, 1976; Pitcher and Busse11, 1977).

\section{Age of Fracture Pattern}

The association of joints with dykes, veins and hydrothermal alteration (e.g.. greisenization, mineral deposits) is generally accepted as evidence for a primary origin of joints in granitic rocks (Ba1k, 1937; Marre, 1986; Hutchinson, 1956; A1len, 1966; Parslow, 1968; Fireman, 1960). The close association of mineralization with late-stage leucocratic units, the recognition of distinct domains of vein types and distinct metallogenic domains associated with certain units, and the avallable geochronological data (Farley, 1978) have led to the conclusion that mineralization in the SMB is related to late- to early-post magmatic processes (McKenzie, 1974, Farley, 1978, Charest, 1979, 0'Reilly et al., 1982; Logothethis, 1984). It would follow that the coincidence of quartz veins (barren and mineralized) with joint trend 4 and dykes with trends 3,4 and 5 indicates $a$ primary origin for these joints. As veining appears to be genetically related to 11thology and is associated with all units of the SMB, it follows that the joint patterns were repeatedly developed during each intrusive event. Thus the causal stress for jointing was present and fixed throughout emplacement of the SMB.

Extensive fracture-related hematitization within the SMB has been considered by Logothetis (1984) to result from deuteric metasomatism. Intense hematitization along trend 2 fractures within the pervasively hematitized leucomonzogranitic units, particulariy zones of fracture cleavage, also suggests that these joints are primary.

Smitheringale (1973) indicated that joints corresponding to trends 3 and 4 are commonly the dominant sets within the Halifax, White Rock, Kentville and Torbrook Formations. He also showed that these joint trends are coincident with minor folds (kink bands) within these rocks and presented evidence that these folds, and hence joints, were developed during granite intrusion.

However, the most convincing evidence for the early development of joints within the SMB is demonstrated by the coincidence of intrusive contacts and the dominant foint trends (2 and 4 ) as outlined above.

\section{Stress Analysis}

The repetition of similar joint patterns throughout the map area, independent of any temporal or spatial restrictions imposed by the geology of the batholith, indicates that the patterns represent through-going features of regional extent. There is generally no simple relation between the joint pattern and the geometry of the units or the orfentation of primary flow features, as would be expected if joints formed in response to emplacement and cooling phenomenon (Balk, 1937; Martin, 1953; Hutchinson, 1956; Davis, 1963; Allen, 1966; Kolde and Bhattacharfi, 1975). This is especially true for the eastern portion of the study area where intrusions and accompanying patterns of flow features are concentric. In the same instance evidence has been given which indicates that these regional trends devoloped during granite emplacement, and in fact repeatedly developed with each intrusive event. Similar observations have been made by Parslow (1968). Busse11 (1976) and Pitcher (1978).

Joint patterns resulting from stresses related to emplacement and cooling are undoubtedly developed to some degree, and may be in part responsible for the girdle nature of the stereonet patterns. Such joints may account for local dyke patterns as outlined above (e.g., those which paralle1 contacts). Secondary folnts, such as those related to faults, are probably also in part responsible for the overall pattern. Nevertheless, a regional fixed-stress was the dominant influence in the development of the dominant regional joint trends.

A composite of joint trends (Fig. 8) shows that a systematic geometric relationship exists among the varlous trends. Trends 2 and 4 are roughly orthogonal and are parallel and perpendicular to reglonal fold trends, respectively. Trends 3 and 5 are symmetrically arranged about trend 4. Similar

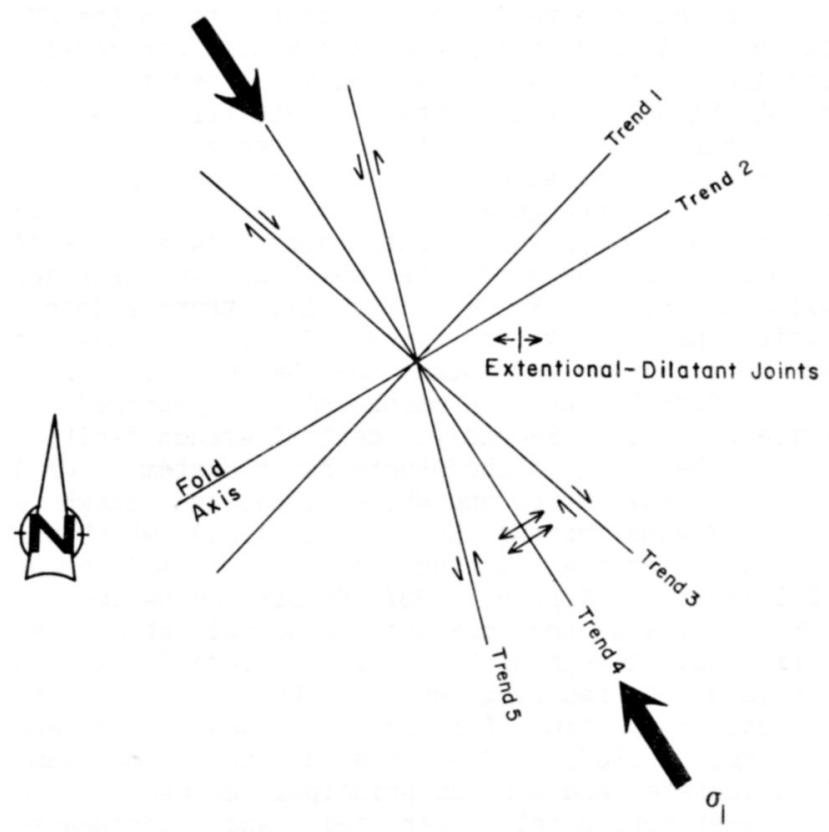

Fig. 8. Geometric relationships between five regional joint sets recognized in the eastern portion of the South Mountain Batholith. 
patterns of regional foints have been discussed by Price (1959), where joints parallel to the main structural trends (trend 2) are referred to as longltudinal, those perpendicular as cross (trend 4), and oblique joints (trends 3 and 5) as shear joints. Primary-regional orthogonal and/or shear joint systems in granite bodies have been described by Titley et al. (1986), Linnen and Williams-Jones (1986). Heldick and Titley (1982), Suryanarayana (1978), P1tcher (1978), Busse11 (1976), Rehrig and Heldick (1972) and Parsiow (1968).

Price (1959, 1966) interpreted such regional joint systems as resulting from residual compressive stress (from the main fold-forming event) during uplift. Vertical shear joints with an acute angle of $40^{\circ}-60^{\circ}$ develop when the maximum principal stress is horizontal and the intermediate principal stress is vertical. Vertical tension joints parallel to the maximum principal stress and bisecting the shear joints could also form at this time. The presence of dykes, representing primary tensional joints, and accompanied shear joints have been interpreted as resulting from compression by Parslow (1968) and Suryanarayana (1978). According to Price, perpendicular vertical tension joints form when the maximum principal stress becomes vertical due to stress release during shear joint development. Uplift at this point will result in a decrease in both the gravitational load (maximum principal stress) and lateral stress resulting in the formation of vertical tension joints parallel to the intermediate principal stress. These foints w1ll bisect the shear joints if the residual regional stress becomes the intermediate stress. The interchange of the intermediate and minimum stress due to stress released during tension foint formation, given that the differential between the two is not too great, results in mutually perpendicular joints parallei and perpendicular the reglonal structural trends.

It would follow from the above discussion that the geometric arrangement of joint sets in the SMB can be explained by regional horizontal compression parallel to trend 4 joints, which are tensional and about which conjugate "shear" joints (trends 3 and 5) occur. The designation of trends 3 and 5 as shear folnts is solely as a consequence of their geometric arrangement, and not on field determination. However, there are a few aspects of joints within the study area which are inconsistent with the model of Price. Firstly, trend 2 joints differ profoundis from trend 4 joints and thus it is difficult to understand how the two folnt sets could form by the same mechanism, as proposed in Price's model. Secondly, dextral wrench faulting along the Cobequid-Chedabucto Fault System (CCFS) (Keppie, 1982; Mawer and White, 1986) and elsewhere In the Meguma Terrane (Henderson, 1986), which was locally active during granite emplacement (Dallmeyer and Keppie, 1987; Kepple and Dallmeyer. 1987). fixes the maximum principal stress as horlzontal throughout this time. Indeed, stress analysis of faulting on the CCFS during Late Carboniferous time (E1sbacher, 1969; Yeo and Ruixing, 1987) demonstrated that maximum, intermediate and minimum principal stresses were northwest-horizonta1, vertical and northeasthorizontal, respectively; these are consistent with those proposed for primary joint formation within the study area. Thus, conditions for perpendicular tensional foint formation in Price's model are not met.

The character of orthogonal foints in Laramide intrusions in Arizona (Rehrig and Heidrick, 1972) is remarkably similar to that described here, with vertical well developed continuous cross joints commonly filled by dykes and veins and poorly developed curviplanar longitudinal joints. Rehrig and Heldrick interpreted the cross foints as tension fractures formed parallel to the maximum principal stress. For the longitudinal joints (trend 2 in this survey) they suggested two possible mechanisms of formation. Firstly, that they represented release fractures formed upon relaxation of regional compression. However, evidence that at least some of these fractures are primary indicates this could not explain all joints of this trend. Secondiy, they proposed that reglonal uplift and lateral stretching augmented by vertical magmatic pressure may be adequate to cause horizontal de-stretching sufficient to form longltudinal joints, as explained by Price. Relative1y rapid uplift has been indicated by the short time span between intrusion, exposure and deposition on top of the batholith.

It is proposed, therefore, that primary-regional joints (trends 2-5) developed within the granites of the eastern part of the SMB resulted from regional northwest-horizontal compression and uplift during granite emplacement. The maximum principal stress as determined for joint formation is similar in orientation to that expected for regional fold development and that which resulted in east-west dextral shearing during Carboniferous time. Regional compression and uplift prior to and later than granite emplacement may have resulted in 1dentical joint patterns. In the latter case, it would be difficult to distinguish primary from secondary regional joints.

Trend 1 is not explained by the above analysis. However, it is well established within the western portion of the study area and forms the dominant trend within the EDP (F1g. 4f). It is also coincident with the general trace of the EDFZ and the elongation of the EDP. Silckensided fractures within the EDFZ (Fig. 9) also yield a maxima corresponding with trend 1 jolnts, suggesting a

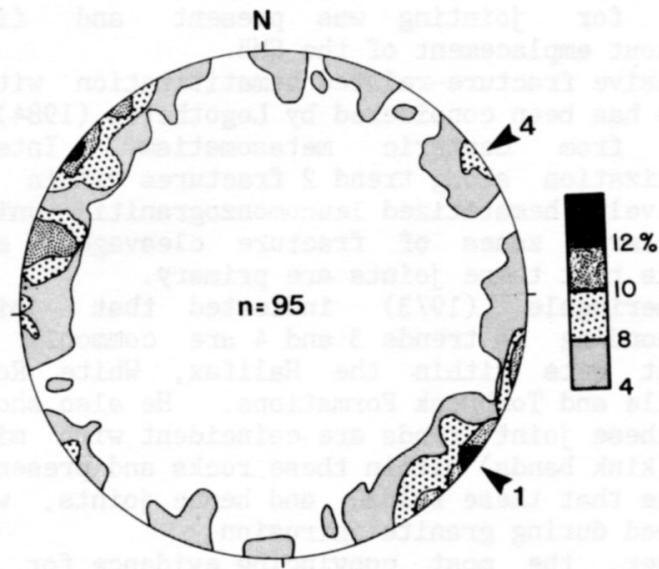

F18. 9. Contoured density plot of poles (n-95) of slickensided fractures within one outcrop in the East Dalhousie Fault Zone. Numbers refer to trends discussed in the text. 
link between the two. Although trend 1 is prevalent in the western portion of the map area, the persistence of trends 3 and 5 (including veins and dykes) suggests that a compressional model is still applicable here. In fact, the parallelism of flow fabrics and trend 3 joints indicates that the former may have formed in response to this same compression. Thus, trend 1 is interpreted as a manifestation of shear which overprints the simple compressional pattern at a local scale.

\section{Economic Significance}

The implications of regional-primary joint patterns in the SMB is obvious in terms of controls on mineralization. An assessment of published data on mineral occurrences in the SMB (0'Reilly et al., 1982, Charest, 1979; McKenzie, 1974) and data from present 1:50,000 scale mapping (MacDonald et al. 1986a, b) demonstrates that the majority of occurrences are assoclated with trend 2 and 4 joints. The style and mineralogy of occurrences are broadly divisible into two types according to the style and orientation of the joints. Northeast-trending fractures and zones of fracture cleavage, which are commonly strongly hematitized are common hosts to uranium mineralization. In contrast, the northwest-trending dilatant fractures are hosts to several vein-greisen style polymetallic $\mathrm{Sn} \pm \mathrm{W} \pm \mathrm{Cu} \pm \mathrm{Mo} \pm$ As occurrences. Regional joint systems such as those described here are considered to be an integral component in the localization of mineralization in porphyry copper systems associated with Laramide intrusions in Arizona (Rehrig and Heidrick, 1972).

\section{CONCLUSIONS}

(1) Primary flow features within the eastern portion of the SMB display concentric- to randomregional patterns in the eastern half and a linearregional (northeasterly-trending) pattern in the western half; thus dividing the area into two distinct domains. These patterns generally reflect the geometry of intrusions.

(2) Northwest-trending sinistral faulting (HCF) in the eastern end of the SMB, consistent with a series of faults in the eastern Meguma Terrane, post-dates granite intrusion. Northeast-trending faulting (EDFZ) within the East Dalhousie Pluton also post-dates granite emplacement.

(3) A primary-regional joint system consisting of steeply dipping northeastly (trend 2) and northwestly (trend 4) orthogonal sets and associated conjugate shear joints (trends 3 and 5) about the northwest set formed in response to northwest, horizontal compression during uplift. Northwest horizontal compression was also responsible for east-west dextral wrench faulting as recorded on the Cobequid-Chedabucto Fault System. An additional joint set (trend 1) associated with the EDFZ has been superimposed on the regional joint trends.

(4) Primary-regional jointing within the SMB has to some degree influenced the emplacement of later magmatic units.

(5) Mineralization within the SMB is commonis controlled by the regional joint sets, with uranium mineralization restricted to northeast-trending (trend 2) joints and polymetallic vein-greisen mineralization restricted to northwest-trending (trend 4) joints.

\section{ACKNOWLEDGEMENTS}

The authors would like to thank P. Smith and D. Nance for their critical reviews, which greatly improved the manuscript. We are grateful to H.A.K. Charlesworth of the Department of Geology, University of Alberta for the unpublished computer program used for stereonet plots. Special thanks is extended to D. Kontak for his conception of this special volume, without which this paper may not have been written. Funding for this research was provided by a joint Nova Scotia-Canada Mineral Development Agreement.

ALLEN, J.C. 1966. Structure and petrology of the Royal Stock, Flint Creek Range. central-western Montana. Grological Society of America Bulletin, 77, pp. 291-302

BALK, R. 1937. Structural Behaviour of Igneous Rocks. Geological Society of America, Memoir 535, 69 p.

BERGER, A.R., and PITCHER, W.S. 1970. Structures in granit1c rocks: a commentary and a critique on granite tectonics. Proceedings of the Geological Association, 81, pp. 441-461.

BUSSELL, M.A. 1976. Fracture control of high-level plutonic contacts in the Coastal Batholith of Peru. Proceedings of the Geological Association, 87, pp. 237-446.

CAMERON, H.L. 1956. Tectonics of the Maritime area. Transactions of the Royal Society of Canada. 3rd ser1es, 50. Section 4. pp. 45-51.

CHAREST, M.H. 1979. Petrology, Geochemistry and Mineralization of the New Ross Area, Lunenburg County, Nova Scotia. M.Sc thes1s. Dalhousie University. Halifax, Nova Scot1a, 154 p.

CLARKE, D.B. and HALLIDAY, A.N. 1980. Strontium isotope geology of the South Mountain Batholith, Nova Scotia. Geochimica et Cosmochimica Acta, 44. pp. 1045-1058.

CLARKE, D.B. and MUECKE, G.K. 1980. Igneous and metamorphic geology of southern Nova Scotia. Geological Association of Canada-Mineralogical Association of Canada, Field Trip Guidebook, 21, $101 \mathrm{p}$

DALLMEYER, R.D. and KEPPIE, J.D. 1987. Polyphase late Paleozolc tectonothermal evolution of the soythwestern Meguma Terrane, Nova Scotia: evidence from ${ }^{40} /{ }^{39} \mathrm{Ar}$ mineral ages. Canadian Journal of Earth Sciences, 24, pp. 1242-1254.

DAVIS, G.A. 1963. Structure and mode of emplacement of Caribou Mountain Pluton, Klamath Mountains, Callfornia. Geological Soclety of America Bulletin, 74, pp. 331-348.

EISBACHER. G.H. 1969. Displacement and stress fleld along part of the Cobequid Fault. Nova Scotia. Canadian Journal of Earth Sc1ences, 6, pp. 1095-1104

FARIBAULT, E.R. 1908. City of Halifax Sheet, Map No. 68. Geological Survey of Canada. Publication No. 1019.

FARLEY, E.J. 1978. Mineralization at the Turner and Walker Deposits. M.Sc. thes1s, Dalhousie University. Halifax. Nova Scot1a, $192 \mathrm{p}$.

FIREMAN, R.J. 1960. The relationship between joints and faults in the Eskdale Granite (Cumberland) and the adjacent Borrowdale Volcanic Series. Journal of the Geological Society of London, 116. pp. 317-347.

FYSON, W.K. 1966. Structures in the Lower Paleozoic Meguma Group, Nova Scot1a. Geological Society of America Bulletin, 77. pp. 931-944.

GILES. P.S. 1985. A major Post-Visean sinistral shear zonenew perspectives on Devonian and Carboniferous rocks of southern Nova Scotia. In Gulde to the Granites and Mineral Deposits of Southwestern Nova Scotia. Edited by A.K. Chatterjee and D.B. Clarke. Nova Scotia Department of Mines and Energy, Paper 85-3. pp. 223-248.

HENDERSON, J.R. 1986. Geology. Ecum Secum area, Nova Scotia. Geolog1cal Survey of Canada. Map 1648A. Scale 1:50.000.

HEIDRICK, T.L., and TITLEY, S.R. 1982. Fracture and dike patterns in Laramide plutons and their structural and tectonic 1mplications. In Advances in Geology of Porphyry Copper Deposits. Edited by S.R. Titley. University of Arizona Press, Tucson, pp. 73-91.

HORNE. R.J. 1987. Preliminary geology of New Germany. is: sheet 21A/10. Nova Scotia Department of Mines and Energy, $\mathrm{OPE}_{\mathrm{F}}$ F1le Map 87-004. Scale 1:50.000.

HUTCHINSON, R.M. 1956. Structure and petrology of Enchantec Rock Batholith, Llano and Gillespie counties, Texas. Geological Soc1ety of America Bulletin, 67, pp. 763-806.

KEPPIE, J.D. 1979. Geological map of Nova Scot1a, Nova Scotia 
Department of Mines and Energy, Scale 1:500,000.

VEPIE, J.D. 1982. The Minas Geofracture. Geological Association of Canada. Special Paper 24, pp. 263-280.

KEPPIE, J.D. 1987. Sedimentology, structure, and metallogeny of the Goldenviile Formation. Meguma Terrane. Isaacs Harbour Nova Scotia. Geological Society of America Centennial Field Culde, Northeastern Section. pp. 433-439.

KEPPIE. J.D. and DALLMEYER, R.D. 1987. Dating transcurrent terrane accretion: an example from the Meguma and Avalon composite terranes in the northern Appalachians. Tectonics, 6 . PP. 831-847.

KNAPP, R.B. and NORTON, D.L. 1981. Preliminary numerical analysis of processes related to magma crystallization and stress evaluation in cooling pluton environments. American Journal of Science, 281, pp. 35-68.

WNOX, G.J. 1974. The structure and emplacement of the Rio Fortaleza Centred acid complex, Ancash, Peru. Journal of the Geological Society of London, 130, pp. 295-308.

KOIDE, H. and BHATTACHARJI, S. 1975. Formation of fractures around magmatic intrusions and their role in ore localization. Economic Geology, 70, pp. 781-799.

LINNEN, R.L., and WILLIAMS-JONES, A.E. 1987. Tectonic control of quartz vein orientations at the Trout Lake stockwork molybdenum deposit, southern British Columbia: implications for metallogeny in the Kootenay Arc. Economic Geology, 82, pp. 1283-1293.

LOGOTHETHIS, J. 1984. The Mineralogy and Geochemistry of Metasomitized Granite rocks from Occurrences in the South Mounta1n Batholith, New Ross area, Southwestern Nova Scotia. M.Sc. thesis, Dalhousie University, Halifax, Nova Scotia, 359 $\mathrm{p}$.

MACDONALD, M.A., COREY, M.C., HAM, L.J., and HORNE, R.J. 1987. South Mountain Batholith project: progress report. In Mines and Minerals Branch. Report of Activities 1987. Part A. Edited by J.L. Bates and D.R. MacDonald. Nova Scotia Department of Mines and Energy, Report 87-5, pp. 99-103.

MACDONALD, M.A. COREY, M.C. HAM, L.J., and HORNE, R.J. 1986a. The geology of the South Mountain Batholith. NTS sheets $21 \mathrm{~A} / 09,21 \mathrm{~A} / 10,21 \mathrm{~A} / 15$ and $21 \mathrm{~A} / 16$ (west). In Mines and Minerals Branch, Report of Activities 1986. Edited by J.L. Bates and D.R. MacDonald. Nova Scotia Department of Mines and Energy, Report 87-1, pp. 119-136.

MACDONALD, M.A. , COREY, M.C., HAM, L.J., and HORNE, R.J. 1986b. South Mountain Batholith project - bedrock mapping. In Program and Summaries, tenth annual review of activities. Edited by J.L. Bates and D.R. MacDonald. Nova Scotia Department of Mines and Energy. Information Series No. 12, pp. 77-81

MACDONALD, M.A., and HORNE, R.J. 1987. Geological map of Halifax and Sambro. NTS Sheets $11 D / 12$ and 11D/05. Nova Scotia Department of Mines and Energy, Map 87-6. Scale 1:50,000.

MCKENZIE C.B. 1974. Petrology of the South Mountain Batholith, Western Nova Scotia. M.Sc. thesis, Dalhousie University, Hallfax Nova Scotia, $101 \mathrm{p}$.

MCKENZIE, C.B., and CLARKE, D.B. 1975. Petrology of the South Mountain Batholith, Nova Scotia. Canadian Journal of Earth Sciences, 12, pp. 1209-1218.

MARRE, J. 1986. The Structural Analysis of Granitic Rocks. E1sevier, New York, 123 p.
MARTIN N.R 1953. The structure of the granite massif of Flamanville, Manche, north-west France. Journal of the Geological Society of London, 108, pp. 311-342

MAWER, C.K., and WHITE, J.C. 1986. Sense of displacement on the Cobequid-Chedabucto fault system, Nova Scot1a, Canada. Canadian Journal of Earth Sciences, 24, PD. 217-223.

O'BRIEN, B.H. 1986. Preliminary report on the geology of the Mahone Bay area, Nova Scotia. In Current research, Part A. Geological Survey of Canada, Paper 86-1A, pp. 439-444.

O'REILLY, G.A. 1987. Geology of the Dean and Chapter manganese mine and surrounding area, Lunenburg County. Nova Scotia. In Mines and Minerals Branch, Report of Activities 1986. Edited by J.L. Bates and D.R. MacDonald. Nova Scot1a Department of Mines and Energy. Report 87-1, pp. 99-105.

O'REILLY G.A. FARLEY, E.J., and CHAREST, M.H. 1982 Metasomat1c-hydrothermal deposits of the New Ross-Mahone Bay area, Nova Scotia. Nova Scotia Department of Mines and Energy, Paper 82-2, $96 \mathrm{p}$.

PARSLOW, G.R. 1968. The physical and structural features of the Calrnsmore of Fleet Granite and 1ts aureole. Scottish Journal of Geology, 4. pp. 91-108.

PITCHER, W.S. 1978. The anatomy of a bathol1th. Journal of the Geological Society of London, 135, pp. 157-182.

PITCHER, W.S., and BUSSELL, M.A. 1977. Structural control of batholithic emplacement in Peru: a review. Journal of the Geological Soclety of London, 133, pp. 249-256.

PRICE, N.J. 1959. Mechanics of jointing in rocks. Geological Magazine, 96. pp. 149-167.

PRICE, N.J. 1966. Fault and Jolnt Development in Brittle and Semi-brittle Rock. Pergamon Press, Oxford, $174 \mathrm{p}$

REHRIG, W.A., and HEIDRICK. T.L. 1972. Reglonal fracturing in Laramide stocks of Arizona and 1ts relationsh1p to porphyry copper mineralization. Economic Geology. 67, pp. 198-213.

REYHOLDS, P.H., ZENTILLI, M. , and MUECKE, G.K. 1981. K-Ar and $\mathrm{Ar} /{ }^{39} \mathrm{Ar}$ geochronology of granitoid rocks from southern Nova Scot1a: Its bearing on the geological evolution of the Meguma Zone of the Appalachians. Canadian Journal of Earth Sciences. 18. pp. 386-394.

SMITHERINGALE, W.G. 1973. Geology of parts of Digby. Bridgetown, and Gaspereau Lake map - areas, Nova Scotia. Geological Survey of Canada, Memoir 379, $74 \mathrm{p}$.

SURYANARAYANA, K.V. 1978. Interpretation of fractures patterns in the porphyritic granites of Triumalai Hill Range, A.P. Indian National Science Academy, 44, pp. 211-217

TAYLOR, F.C., and SCHILLER, E.A. 1966. Metamorphism of the Meguma Group of Nova Scotia. Canadian Journal of Earth Sciences, 3. pp. 959-974.

TITLEY, S.R., THOMPSON, R.C. HAYNES, F.M., MANSKE, S.L. ROBISON, L.C., and WHITE, J.L. 1986. Evolution of fractures and alteration in the Sierrita Esperanza hydrothermal system. Pima county, Arizona. Economic Geology, 81, pp. 343-370.

WRIGHT, W.J. 1931. Data on the method of granite intrusion in Nova Scotia. Transactions of the Royal Society of Canada, 3rd series, 25, pp. 309-327

YEO, G.M., and RUIXING, G. 1986. Late Carboniferous dextral movement on the Cobequid-Hollow fault system, Nova Scotia: evidence and implications. In Current Research. Part A. Geological Survey of Canada. Paper 86-1A. pp. 399-410. 